\title{
Effects of structural factors on upwelling fouling community, Southeast Brazil
}

\author{
Bruno Pereira Masi ${ }^{1}$, Ilana Zalmon ${ }^{2}$, Ricardo Coutinho ${ }^{3}$
}

\author{
${ }^{1}$ Universidade do Estado do Rio de Janeiro. \\ ${ }^{2}$ Universidade Estadual do Norte Fluminense Darcy Ribeiro. \\ (Av. Alberto Lamego 2000, 28013-602, Campos dos Goytacazes, RJ, Brazil.) \\ ${ }^{3}$ Instituto de Estudos do Mar Almirante Paulo Moreira. \\ (Divisão de Biotecnologia Marinha, Rua Kioto 253, 28930-000, Arraial do Cabo, RJ, Brasil.) \\ *Corresponding author: ilana@uenf.br
}

\begin{abstract}
To assess the successional pattern of fouling organisms three hypotheses were tested: 1) a thermocline is caused by seasonal upwelling events, and therefore, depth influences the successional trajectory of the fouling community; 2) a reduction in the intensity of natural light of the substrate influences the fouling composition and the successional trajectory; 3 ) fish predation influences the community composition and its successional trajectory. During one year, up-facing and downfacing PVC panels on open, partially caged or fully caged, and placed at depths of 1.5 and 3.5 meters were monthly sampled by digital photograph to determine the community composition and by contact point to estimate the percent coverage of organisms. The upwelling impact provided different water masses, and light intensity was also a determining factor of the overall successional trajectory of the fouling community. After the installation of full and partial cages, differences were identified in the respective successional trajectories. The results of this study suggest that each physical factor or biological process can change the successional trajectory of the community, and the successional model (e.g., convergent, divergent, parallel, or cyclic) depends on the magnitudes of the determinants that act on the community at each stage of its trajectory.
\end{abstract}

Descriptors: Biofouling, Successional processes, Multi-experimental design, Predation.

\section{RESUmo}

Para avaliar o padrão sucessional de organismos incrustantes, três hipóteses foram testadas: 1) uma termoclina é causada por eventos de ressurgência e, portanto, a profundidade influencia na trajetória sucessional da comunidade incrustante; 2) a redução na intensidade de luz natural no substrato influencia a composição da comunidade e a trajetória sucessional; 3) a predação por peixes influencia a composição da comunidade e sua trajetória sucessional. Durante um ano, faces inferiores e superiores de painéis de PVC em gaiolas abertas, parcial e totalmente fechadas em profundidades de 1,5 e 3,5 metros foram amostradas mensalmente por fotografia digital para determinar a composição da comunidade por ponto-contato e estimar a porcentagem de cobertura dos organismos. Diferentes massas de água resultantes da ressurgência e diferentes intensidades de luz foram fatores determinantes na trajetória sucessional da comunidade. Após a instalação de gaiolas parcial e totalmente fechadas, foram identificadas diferenças nas respectivas trajetórias. O resultado deste estudo sugere que cada fator físico ou processo biológico pode alterar a trajetória de desenvolvimento de uma comunidade, e o modelo sucessional (ex. convergente, divergente, paralelo ou cíclico) depende da magnitude dos fatores determinantes que atuam em cada etapa de sua trajetória.

Descritores: Bioincrustação, Processos sucessionais, Desenho multi-experimental, Predação. 


\section{INTRODUCTION}

Ecological succession is the changing pattern in the composition and abundance of organisms at a given spatial scale over time (CONNELL; SLATYER, 1977; TILMAN, 1990). This concept is fundamental to the principles of community ecology and has been studied based on sequential in situ observations over specific units of time using experimental manipulations and/or conceptual models (reviewed by PRACH; WALKER, 2011). The predominant mechanisms involved in the ecological succession of benthic communities are: facilitation, inhibition and tolerance (CONNEL; SLATYER, 1977), multiple stable points (SUTHERLAND; KARLSON, 1977), random colonisation (LAWTON, 1987), and competition between individuals (HUSTON; SMITH, 1987).

The benthic rocky shore community can be viewed as a mosaic of patches at different successional stages (MENGE et al., 2005). The first substantial application of the idea of multiple stable states in marine community ecology was proposed by SUTHERLAND (1974), i.e., differences in life history driven by repeated disturbances that continuously cause permanent changes. The temporary climax described by SUTHERLAND and KARLSON (1977) and SUTHERLAND (1984) occurs because of the life histories of its components, the availability of resources, or the presence of numerous potentially dominant species.

Several studies have identified environmental factors and biological processes that can explain different fouling community patterns, such as the role of environmental stress (SOUSA, 2001), depth (STARK, 2008), sedimentation and light intensity (IRVING; CONNELL, 2002), shade (GLASBY, 1999), and predation (CONNELL; ANDERSON, 1999).

Successional patterns in communities related to consolidated substrates vary with water depth (BRAM et al., 2005). According to these authors, depth affects the intensity of recruitment and the distribution and coverage of late successional species, but does not influence the early development sequence of the community ( $<4$ months). These depth effects on the composition and structure of benthic communities were observed on artificial substrates in the Baltic Sea by QVARFORDT et al. (2006) and in Ryder Bay, on the Antarctic Peninsula, by STARK (2008).

The light propagation decreases with depth in marine environments, which is a determining factor of the structure and function of phytobenthic communities (reviewed by RIER et al., 2006). Additionally, observations indicate that marine invertebrates are dominant in shaded surfaces (GLASBY, 1999), as the larval stages of many marine invertebrates display photonegative behaviour (PAWLIK, 1992).

Seasonality in coastal benthic ecosystems causes environmental fluctuations in parameters such as temperature and nutrient enrichment (COMA et al., 2000). According to HINRICHSEN (2009), the physical oceanographic variables of greatest importance for species biology and behaviour are the sea surface temperature, the mixing of waters of different depths, the presence and depth of the thermocline, the strength of upwelling, surface ocean currents, and sea ice. The Cabo Frio region, located on the southeast coast of Brazil, is subjected to the seasonal upwelling of cold water from the south, with lower water temperatures $\left(<18{ }^{\circ} \mathrm{C}\right)$ occurring during spring and summer, and higher water temperatures during fall and winter, the period with low frequency of upwelling events. During the austral spring-summer, the upwelling events are prevalent and cause stratification of the water column and the intrusion of cold, nutrient-rich waters even in shallower ones. During the austral autumn-winter, there is a homogenization of the water column. Lower temperatures, as low as $13{ }^{\circ} \mathrm{C}$, and higher nitrate and phosphate concentrations, approximately 10 and $0.8 \mu \mathrm{g}$ at. $1^{-1}$, respectively, characterize the upwelling conditions (GUIMARAENS et al., 2005). According to MASI et al. (2015), the intensity and frequency of seasonal upwelling events might affect the environmental variability due to particular oceanographic characteristics and may influence the level of stress that the fouling community experiences, with divergent successional trajectories.

Among biotic factors, the relative importance of predation at different successional stages of the community depends on the magnitude of the recruitment rate and strength of the predator-prey interaction (VIEIRA et al., 2012), which may be strongly related to the predator species in benthic communities of consolidated natural (CONNELL; ANDERSON, 1999) and artificial (HACKRADT et al., 2011) substrates.

Manipulative experiments can identify different associations of fouling organisms but are restricted to the temporal and spatial scales at which they are conducted. Currently, a major challenge of ecological studies concerned with fouling communities is the determination of the magnitudes of the community structuring factors. 
A multi-experimental approach related to simultaneous experiments with identical access to the environmental characteristics allows for the examination of the influence of each factor or biological process on various ecological assemblages over time. Additionally, experiments conducted in upwelling ecosystems also help to further elucidate the connections among pelagic and benthic processes (reviewed by LÓPES; COUTINHO, 2008; MAZZUCO et al., 2015).

The aim of the present study was to investigate the structuring factors of fouling communities in a tropical upwelling ecosystem by monitoring their successional trajectories on experimental panels, and simultaneously investigating the effects of depth, orientation of the substrate, and fish predation. Three hypotheses have been tested: $H_{1}$. A thermocline is created in association with seasonal upwelling events, and consequently, depth influences the successional trajectory of the fouling community; $\mathrm{H}_{2}$. The orientation of the substrate, which dictate the intensity of natural light, influences the composition of the fouling community and, consequently, the successional trajectory; $\mathrm{H}_{3}$. Fish predation influences the composition of the benthic community and, therefore, the successional trajectory of the fouling community.

\section{MATERIAL AND METHODS}

The study was conducted at Cabo Frio Island (2300'04.46” S, 4200'20.19' W), southeastern Brazil (Figure 1), in a small sandy cove surrounded by rocky shores, where upwelling events are frequent and intense. VALENTIN et al. (1987) have demonstrated the significant influence of the local winds on the fluctuation in the thermocline. Discrete upwelling events may occur throughout the year but are more intense and frequent during the spring-summer months (GUIMARAENS et al., 2005). Sedimentation rates for open waters in the Cabo Frio upwelling zone range from $0.26 \mathrm{~mm}$ year $^{-1}$ to 0.66 mm.year-1 (MAHIQUES et al., 2005), and there is no continental influence on shallow waters that could alter this condition.

\section{EXPERIMENTAL DESIGN}

Five multi-experiment units were affixed to the substrate and each individually supported three experimental PVC panels $(20 \times 15 \mathrm{~cm})$, arranged horizontally, at two different depths, approximately 1.5 and $3.5 \mathrm{~m}$ (Figure 2). The local depth is around $5 \mathrm{~m}$ and

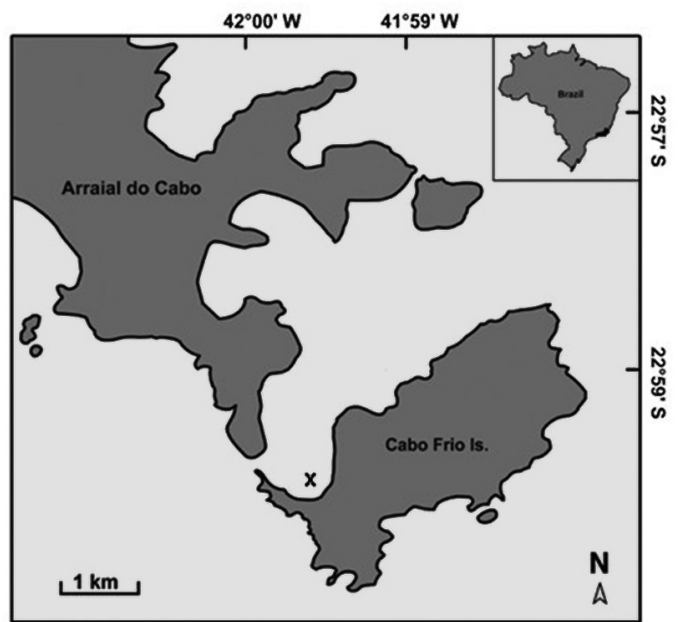

Figure 1. Location of the study area $(\times)$ on the Cabo Frio Island, Rio de Janeiro, southeastern Brazil.

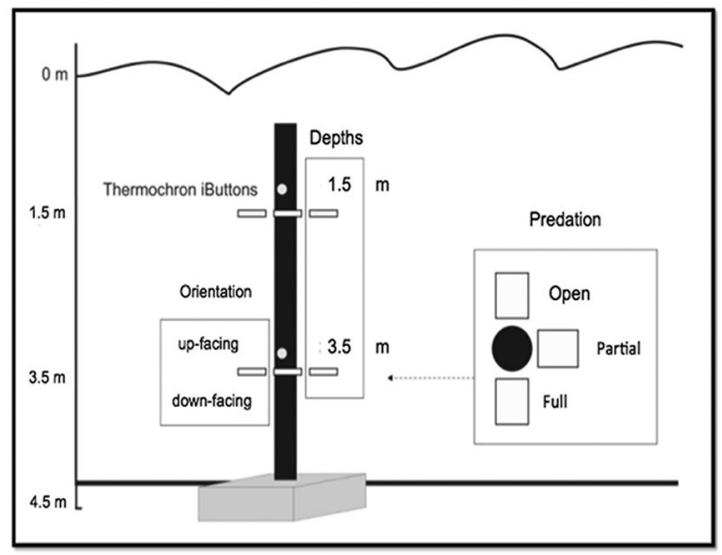

Figure 2. Schematic of the multi-experimental biofouling structure. The treatments are depicted with their respective levels. Depth: 1.5 and $3.5 \mathrm{~m}$; Orientation: up-facing and down-facing; Predation: open panel, partially caged panel and fully caged panel.

tidal variation is approximately $1.5 \mathrm{~m}$. Each structure was composed of a PVC tube $(5 \mathrm{~m}$ high and $20 \mathrm{~cm}$ diameter) supported on a cement block weighing approximately 350 $\mathrm{kg}$. The multi-experiment units were placed at a distance of $10 \mathrm{~m}$ from each other, parallel to the beach line.

\section{THE MULTI-EXPERIMENT DESIGN ADDRESSED}

\section{THREE EFFECTS:}

a. Effect of depth was assessed at two levels (1.5 and 3.5 m) with panels inserted horizontally in the experimental structure fixed to the substrate. The presence of distinct water masses distributed vertically along the water column and temporally across periods of upwelling was assessed with sensors (DS1921H/Z Thermochron ${ }^{\circledR}$ iButtons $^{\circledR}$ ) that 
recorded the temperature every hour simultaneously at the two experimental depths throughout the panel immersion period, from July 2009 to July 2010.

b. Effect of light was tested by analysing two panel orientations: 1) up-facing and 2) down-facing. The light intensity was measured near the surface of the panels (down-facing $\mathrm{X}$ up-facing), with $\mathrm{N}=28$ down-facing panels and $\mathrm{N}=28$ up-facing panels). The coefficient of light extinction was calculated by in situ measurements with a Li-cor data logger (LI-1000) coupled to a LI-193SA Underwater Spherical Quantum Sensor. Since there was no significant difference on light intensity of the same face on different depths, and due to the higher hydrodynamics at the shallower depth, the light effect was tested on 3.5 $\mathrm{m}$ panels.

c. Effect of fish predation was tested at the 3.5-m depth, also due to higher hydrodynamics at the shallower depth, and included three levels: 1) open panel, freely accessed by fish, 2) fully caged panel, to exclude fish, and 3) partially caged panel to control for the exclusion artefact. The effectiveness of the cages was examined by comparing the open and partially caged panels. The panels were immersed for six months without any treatment, and subsequently, the cages were inserted to examine the effects of fish predation on the already established community. Full and partial cages were constructed of plastic $1-\mathrm{cm}^{2}$ mesh screens to prevent access by all fish, except small juveniles and families such as Blenniidae and Gobiidae, which are not usually predators of sessile epibiota according to Connell (2001). Physical cleaning of the cages was performed every 10 days by removing organisms attached to the mesh screen.

Experimental panels were immersed on 17 July 2009 and four subsequent fouling community samplings were performed: 19 October 2009 (month 3), 17 January 2010 (month 6), 15 April 2010 (month 9), and 27 July 2010 (month 12). Divers performed non-destructive sampling by collecting in situ photographs, which prevented possible interferences generated by the manipulation of the panels and provided a permanent photographic record of the data. Photographic sampling was conducted using a 12-megapixel digital camera (model DC1200 SeaLife) in the macro mode, designed for short fixed distances.

The pictures were analysed using the Coral Point Count software with Excel extensions (CPCe - KOHLER; GILL, 2006), in which a rectangular area is selected in the digital image and 100 points are distributed in a grid (10 rows and 10 columns); then, the percentages of points that are covered by each functional group are estimated. Thus, the relative abundance of the biota is calculated.

The taxonomic nomenclature followed the 'ITIS Integrated Taxonomic Information System’ (ITIS, 2009). Discrete functional or taxonomic groups were defined based on DE MESSANO et al. (2009). Encrusting coralline algae (Corallinales, Rhodophyta) were identified as an exclusive functional group.

The fish community was sampled qualitatively by the stationary visual observation method adapted from BROTTO et al. (2007), in which the diver records the presence of fish for 5 minutes at a distance of 3 metres. Fish were grouped into trophic categories based on the main diets of adults following FERREIRA et al. (2004). The interaction behaviour was classified as 'feeding' when a fish was preying on panel organisms, as 'shelter' when a fish remained stationary above or next to the panels, and as 'no interaction' when a fish was only observed swimming close to the experimental structure.

\section{DATA ANALYSIS}

The structure of the thermal dome was assessed by the differences in temperature measured simultaneously between 1.5 and $3.5 \mathrm{~m}$. Values equal to 0 indicate homogeneity of the water column, whilst negative and positive values indicate vertical heterogeneity of the water column. Negative values show thermal dome inversion with higher temperature at $3.5 \mathrm{~m}$. The temperature was determined by the number of upwelling events measured in each study month. The differences in the average light intensity values on both depth and orientation treatments were analysed by Student's t-tests.

The biofouling community structure was compared considering two sampling depths (1.5 and $3.5 \mathrm{~m})$, the panel orientation (down-facing and up-facing) and the predation influence (open panel, fully and partially caged panel) through a matrix of the species percent cover (arcsinesquare-root transformed data) of the representative species and through a non-metric multidimensional scaling (nMDS) ordination using the Bray-Curtis similarity index (CLARKE; WARWICK, 2001). The comparative analysis of the community considering each treatment included an analysis of similarity (ANOSIM) to test for significant differences. The species' contributions to the similarities among assemblages were calculated using the identification of fouling associations (CLARKE; WARWICK, 2001). The multivariate analyses were performed using the PRIMER v.6 statistical software. 


\section{RESULTS}

During the immersion panels, 4,505 temperature records were collected at each depth. The minimum and maximum temperatures were higher at the shallower depth (1.5 m: 15 and $33{ }^{\circ} \mathrm{C} ; 3.5 \mathrm{~m}$ : 13.5 and $\left.31.5{ }^{\circ} \mathrm{C}\right)$. The greatest differences in temperature between depths occurred from September 2009 to March 2010, which corresponds to the austral spring-summer period (Figure $3)$. This stratification in the water column indicates the high frequency of upwelling events during this period.

The average light intensity on the up-facing surface of the panels was $792.9 \pm 52.5 \mu \mathrm{mol} \mathrm{s} \mathrm{m}^{-1} \mathrm{~m}^{-2}$ at $1.5 \mathrm{~m}$, and $797.2 \pm 43.3 \mu \mathrm{mol} \mathrm{s} \mathrm{s}^{-1} \mathrm{~m}^{-2}$ at $3.5 \mathrm{~m}$, with no significant difference $(p=0.82$ ) (Figure $4 \mathrm{a})$. At $3.5 \mathrm{~m}$, a significantly ( $p=0.00$ ) lower light intensity was observed for the downfacing surfaces $\left(156.5 \pm 11.2 \mu \mathrm{mol} \mathrm{s}^{-1} \mathrm{~m}^{-2}\right)$ compared to the up-facing surfaces $\left(792.9 \pm 52.5 \mu \mathrm{mol} \mathrm{s}^{-1} \mathrm{~m}^{-2}\right)$ (Figure $\left.4 \mathrm{~b}\right)$.

Considering all the treatments (depth, light and predation), the fouling community included seven taxonomic groups of invertebrates and six functional groups of algae. Filamentous macroalgae (Ectocarpaceae), sponges (Amorphinopsis sp., Dysidea etherea, Oceanapia nodosa and Mycale microsigmatosa), hydroids (Pennaria sp. and Obelia dichotoma), and barnacles (Megabalanus coccopoma, Amphibalanus amphitrite and Balanus trigonus) occurred in all the treatments. Diatoms (Nitzschia and Navicula) and articulated calcareous macroalgae (Jania sp.) were not recorded on the down-facing surface of the panels. Corticated macrophyte (Codium spongiosum) was observed on the down-facing surface and in the fully caged panels. Mussel (Perna perna) and gastropods (Anachis and Stramonita haemastoma) were observed on the partially and fully caged panels. Fouling bryozoans (Savignyella lafonti and Schizoporella errata) were absent at $1.5 \mathrm{~m}$, and colonial ascidians (Symplegma spp and Didemnum spp) were observed at $1.5 \mathrm{~m}$ and in the fully caged panels (Table 1).

Discrimination between biofilm 1 and 2 was performed based on observations of different colours and their occurrence at different stages in the successional trajectory: biofilm 1 was present first after the substrate was immersed and biofilm 2 during the successional trajectory.

\section{EFFECT OF DEPTH}

The fouling community differed significantly between the 1.5 and $3.5 \mathrm{~m}$ depths at the month 3 (ANOSIM: $\mathrm{r}=0.81$, $p=1.8 \%$ ) and month 6 (ANOSIM: $\mathrm{r}=0.462, p=3.6 \%$ ). At month 9 (ANOSIM, $\mathrm{r}=0.21, p=16.1 \%$ ) and month 12 (ANOSIM, $\mathrm{r}=0.174, p=21.4 \%$ ), the depth effect was not significant. At 9 and 12 months, the sampling units were more dispersed in the n-MDS ordination, showing that the successional trajectories do not converge at the different depths (Figure 5).

The dissimilarity between the associations at the 1.5- and 3.5-m depths increased along the successional trajectory (SIMPER: month $3=22.7 \%$, month $6=35.3 \%$, month $9=50.5 \%$, month $12=58.6 \%$ ), and seven taxonomic

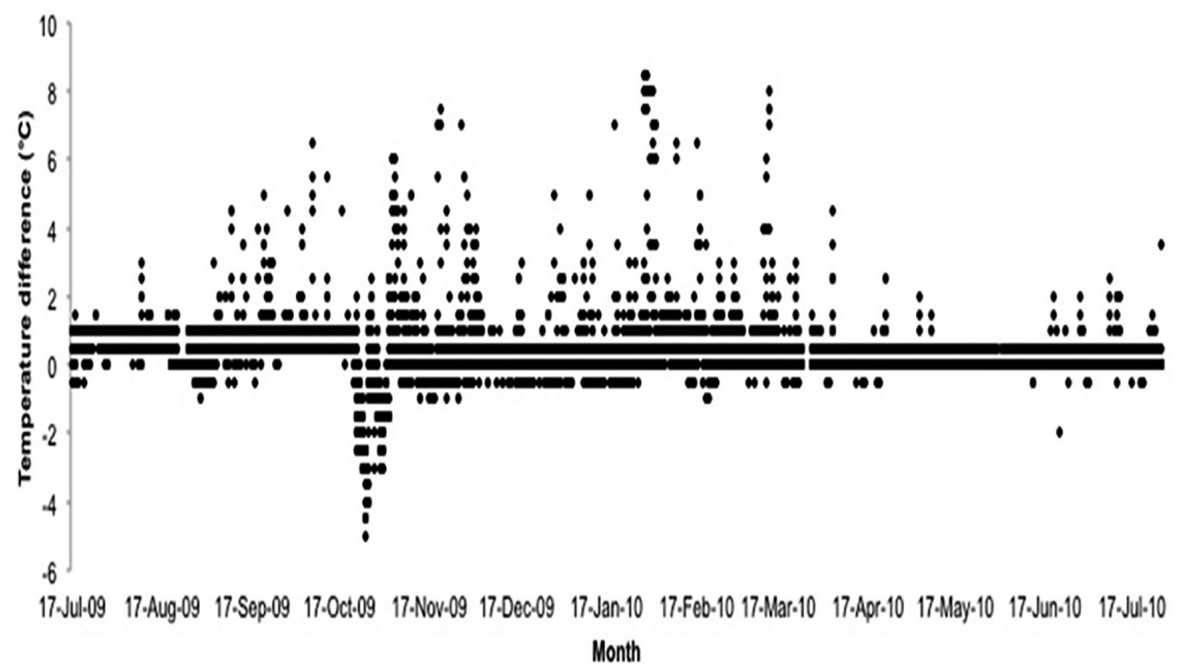

Figure 3. Temperature difference between the depths of 1.5 and $3.5 \mathrm{~m}$, indicating the heterogeneity of the water column on Cabo Frio Island during the immersion period of the experimental panels. 
(a)

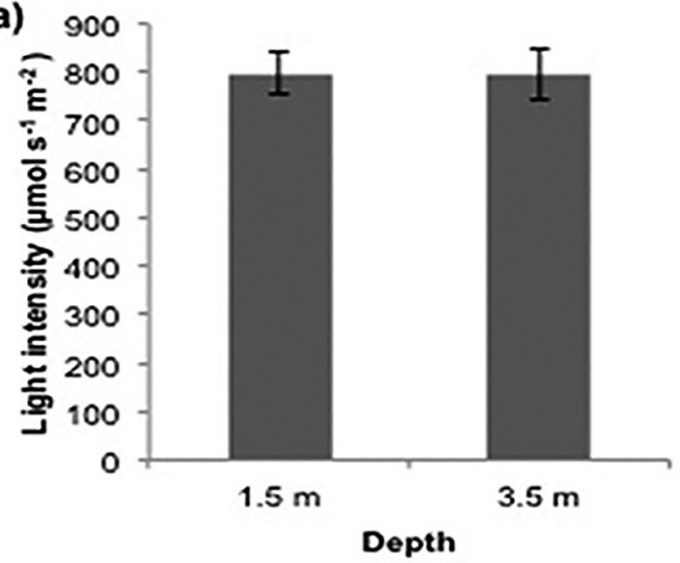

(b)

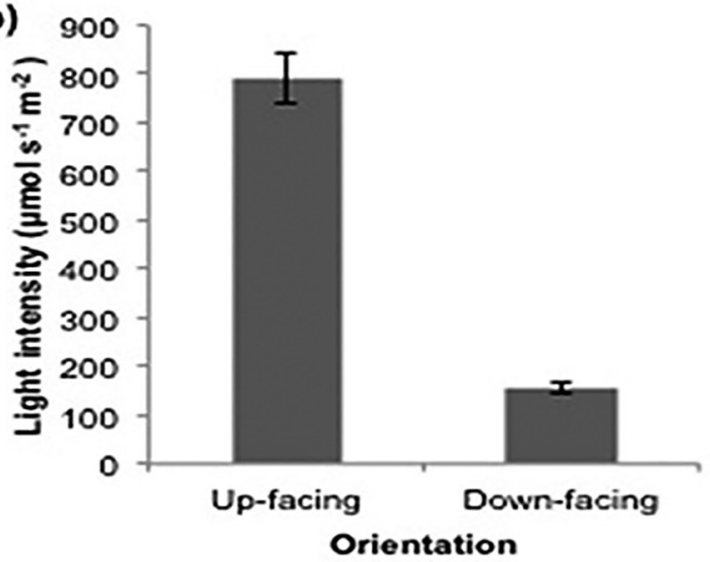

Figure 4. Mean values and standard deviations of light intensity $\left(\mu \mathrm{mol} \mathrm{s} \mathrm{s}^{-2}\right)$ on the up-facing surface of the experimental panels in Cabo Frio Island at the 1.5- and 3.5-m depths (A) and on the up- and down-facing surfaces of the $3.5-\mathrm{m}$ panels.

Table 1. Taxonomic (invertebrates) and functional (algae) groups recorded on the experimental panels at Cabo Frio Island from July 2009 to July 2010. Functional groups are indicated in the text by the code recorded in the second column.

\begin{tabular}{|c|c|c|c|c|c|c|c|c|}
\hline Group & Code & $1.5 \mathrm{~m}$ & $3.5 \mathrm{~m}$ & Up-facing & Down-facing & Open panel & Full cage panel & $\begin{array}{l}\text { Partial cage } \\
\text { panel }\end{array}$ \\
\hline Biofilm 1 & $\mathrm{BI}$ & + & + & + & - & + & + & + \\
\hline Biofilm 2 & MI & + & + & + & - & + & + & + \\
\hline $\begin{array}{l}\text { Articulate calcareous } \\
\text { Algae }\end{array}$ & $\mathrm{CA}$ & + & + & + & - & + & + & + \\
\hline Crostose algae & $\mathrm{CR}$ & + & + & + & + & + & + & - \\
\hline Filamentous algae & FI & + & + & + & + & + & + & + \\
\hline Corticated macrophytes & $\mathrm{MC}$ & - & - & - & + & - & + & - \\
\hline Sponge & ES & + & + & + & + & + & + & + \\
\hline Hydrozoa & HI & + & + & + & + & + & + & + \\
\hline Bivalve & BI & - & - & - & - & - & + & + \\
\hline Gastropoda & GA & - & - & - & - & - & + & + \\
\hline Cirripedia & $\mathrm{CI}$ & + & + & + & + & + & + & + \\
\hline Encrusting bryozoan & BI & - & + & + & + & + & + & + \\
\hline Colonial ascidian & $\mathrm{AC}$ & + & - & - & - & - & + & - \\
\hline
\end{tabular}

groups contributed the most to these differences (Figure 6): filamentous algae at month 3 (Figure 6a); filamentous algae, biofilm 2, barnacles and hydroids at month 6 (Figs 6a, b, c, d); filamentous algae, barnacles, and hydroids at month 9 (Figure 6a, c, d); hydroids, articulate calcareous algae and sponges at month 12 (Figure 6d, e, f). The amount of bare space increased until month 9 (Fig $6 \mathrm{~g}$ ).

\section{EFFECT OF LIGHT}

The effect of the substrate orientation on the fouling community was significant, with differences between the up-facing and down-facing of the experimental panels on both successional trajectory: month 3 (ANOSIM: $\mathrm{r}=0.898, p=0.8 \%$ ), month 6 (ANOSIM: $\mathrm{r}=0.99, p=0.8 \%$ ), month 9 (ANOSIM: $\mathrm{r}=0.62, p=1.6 \%$ ), and month 12 (ANOSIM: $\mathrm{r}=0.714, p=0.8 \%$ ). The differences among panel surfaces are evident in the n-MDS plot, in which the sampling units of the up-facing panels are located in the upper half of the plot and those of the down-facing panels are located in the bottom half (Figure 7). At 3 months, the samples from both panel sides are close together, whilst the samples become more dispersed in the plot in the later stages of succession, demonstrating that the successional trajectories of the associations on the up-facing and down-facing panel surfaces do not converge (Figure 7). 


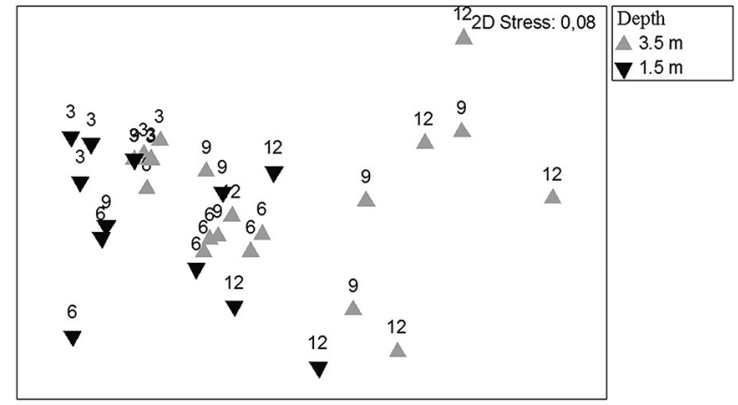

Figure 5. Non-metric multidimensional scaling of the fouling community at each sampling period $(3,6,9$, and 12 months $)$ and depth (1.5 and $3.5 \mathrm{~m})$.

The dissimilarity between the communities of the upand down-facing surfaces of the panels increased along the successional trajectory (SIMPER: month $3=22: 16 \%$, month $6=54.4 \%$, month $9=59.4 \%$, month $12=72.2 \%$ ); nine taxonomic groups contributed the most to these differences (Figure 8): filamentous algae at month 3 (Figure 8a); filamentous algae, hydroids, barnacles, and biofilm 2 at month 6 (Figure 8a, b, c, d); hydroids, barnacles, encrusting bryozoans, and crustose calcareous algae at month 9 (Figure 8b, c, e, f); hydroids, barnacles, encrusting bryozoans, articulate calcareous algae, and sponges at month 12 (Figure 8b, c, e, g, h). Bare space was
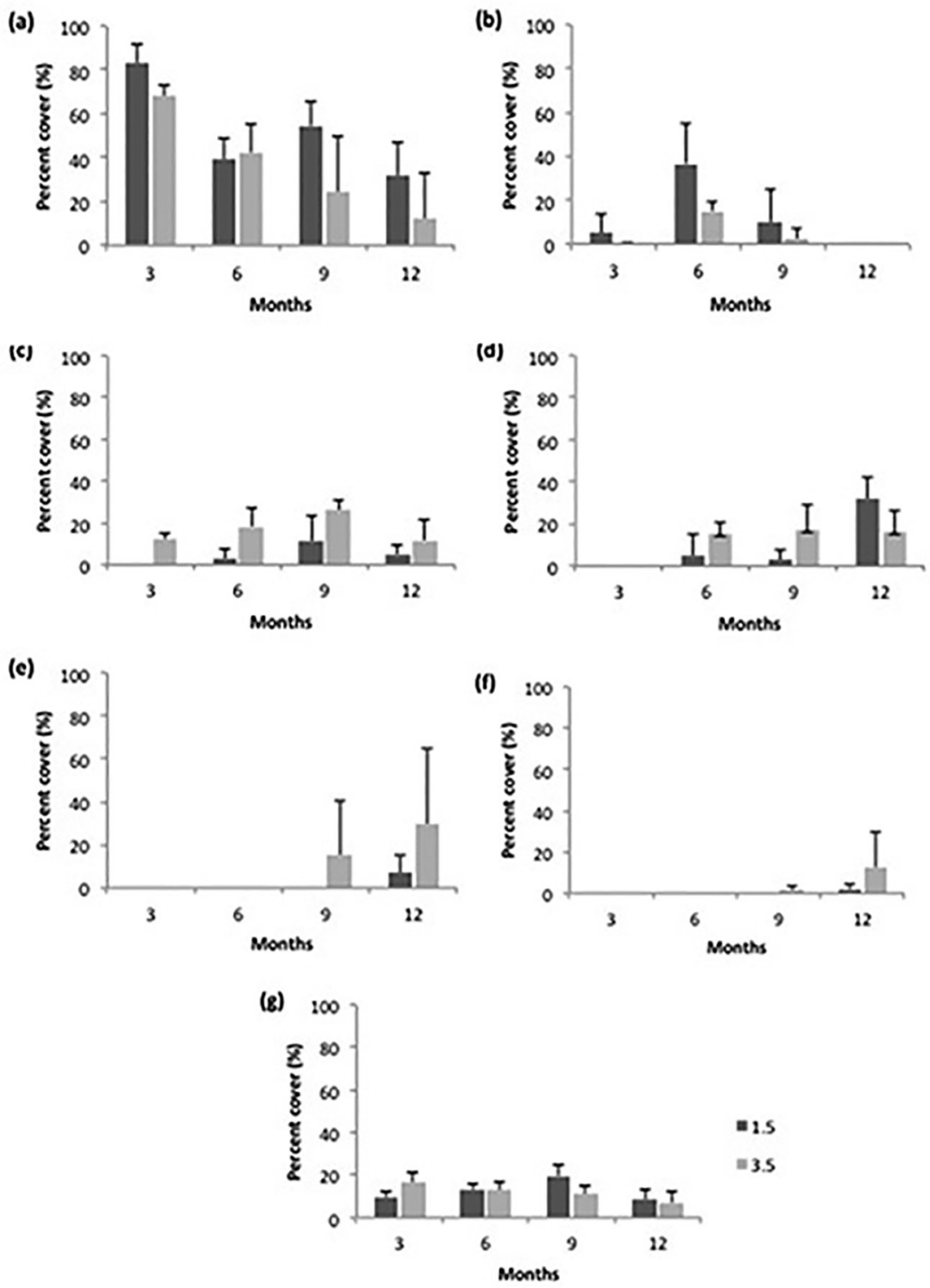

Figure 6. Mean values and standard deviations of the percent cover of the fouling organisms that contributed most to the dissimilarity between the 1.5- and 3.5-m depths at 3, 6, 9 and 12 months (a. Filamentous algae, b. Biofilm 2, c. Cirripedia, d. Hydrozoa, e. Articulate calcareous algae, f. Sponge, g. Bare space). 


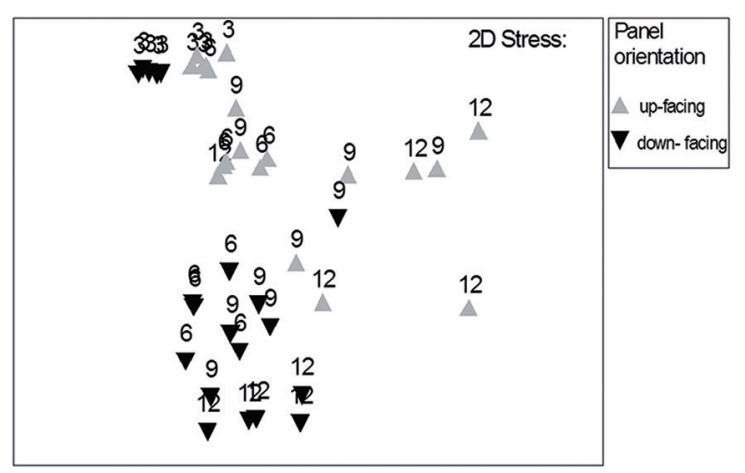

Figure 7. Non-metric multidimensional scaling of the fouling community at each sampling period ( $3,6,9$, and 12 months) and panel orientation (up-facing and down-facing).

more abundant on the up-facing surface at almost all stages, although with a decreasing trend (Figure 8i).

\section{EFFECT OF PREDATION}

The fouling community differed significantly on the open and fully caged panels at month 9 (ANOSIM: $\mathrm{r}=0.231, p=2.7 \%$; Dissimilarity $=58.7 \%$ ) and month 12 (ANOSIM, $\mathrm{r}=0.339, p=2.2 \%$; Dissimilarity $=59.6 \%$ ). The effectiveness of the exclusion artefact, when comparing the open panel and partially caged treatments, resulted in significant differences at 9 (ANOSIM: $\mathrm{r}=0.356, p=1.6 \%$; Dissimilarity $=52.5 \%$ ) and 12 months (ANOSIM: $\mathrm{r}=0.448$, $p=2.4 \%$; Dissimilarity $=66.6 \%$ ). The taxonomic groups that contributed to these differences the most were hydroids (33.3\%), articulate calcareous algae (26.2\%), and sponges (28.8\%).

In the period preceding the exclusion treatment ( 3 and 6 months), the panels were dominated by filamentous algae and biofilm 2 (Figure 9a, b). At 9 months, the open panels were characterised by filamentous algae and barnacles (Figure 9a, c), and the panels with partially and fully caged panels were dominated by hydroids (Figure 9d). At 12 months, the open panels were predominated by cirripedia and articulate calcareous algae (Figure 9c, e), the fully caged panels by hydrozoa and sponges (Figs 9d, f), and the partially caged panels by articulate calcareous algae and sponges (Figure 9e, f). The proportion of bare space did not differ between the exclusion treatments and displayed a decreasing trend (Figure 9g).

The qualitative sampling of the fish community surrounding the multi-experimental biofouling structure recorded 12 species including five trophic categories (Table $2)$ : omnivores $(\mathrm{n}=5)$, invertivores $(\mathrm{n}=3)$, carnivores $(\mathrm{n}=2)$, herbivores $(n=2)$ and piscivores $(n=1)$. Interactions of fish with the fouling community for food ( $\mathrm{n}=5$ species) and shelter ( $\mathrm{n}=3$ species) were observed for the carnivorous, invertivorous and omnivorous fish. The herbivorous and piscivorous fish were not recorded interacting with the experimental panels (Table 2).

\section{DISCUSSION}

The environmental stress can be considered a disturbance that redefines the successional processes of communities at different stages, creating the mosaic pattern that characterise several marine ecosystems (SOUZA, 2001). The characteristics of each patch may vary due to intrinsic and extrinsic factors, including species interactions, dispersal, physical disturbance and environmental stress (MENGE et al., 2005). The patch isolation represented by the experimental panels increased their independence, enabling the formation of different assemblages. On a quarterly scale, the sampling units exhibited an increasing dissimilarity over 12 months, probably due to the spatial heterogeneity in the fouling composition that resulted from the panel isolation in the various multi-experimental structures, generating independent samples.

A multi-experimental approach, such as that employed in the study, maximises the amount of general information concerning the main structuring factors of the community, allowing for the assessment of the influence of a single factor and the ones to be considered in future multiexperimental designs (ROBERTS et al., 2011; CONNELL, 2001). For ecological succession, three components should be considered, according to PRACH and WALKER, 2011: the model, stages, and trajectory. Hereafter, the effects of the factors that structure the fouling community were analysed by addressing these components.

Considering the effect of depth along the successional trajectory, significant differences were observed in the fouling community between 1.5 and $3.5 \mathrm{~m}$ after 3 and 6 months of immersion. These stages correspond to the spring-summer months, when the largest number of upwelling events occurred, especially at the $3.5 \mathrm{~m}$ depth, causing vertical oscillations in the thermocline. According to VALENTIN et al. (1987), these oscillations induce the temporary formation of a thermal dome, resulting in the intrusion of deep cold waters that are rich in nutrients. The spatial (depth) and temporal (seasonal upwelling) variability of the hydrological patterns in the study area can cause disturbances that are realised as variations in temperature and, hence, in the supply of larvae. According to 

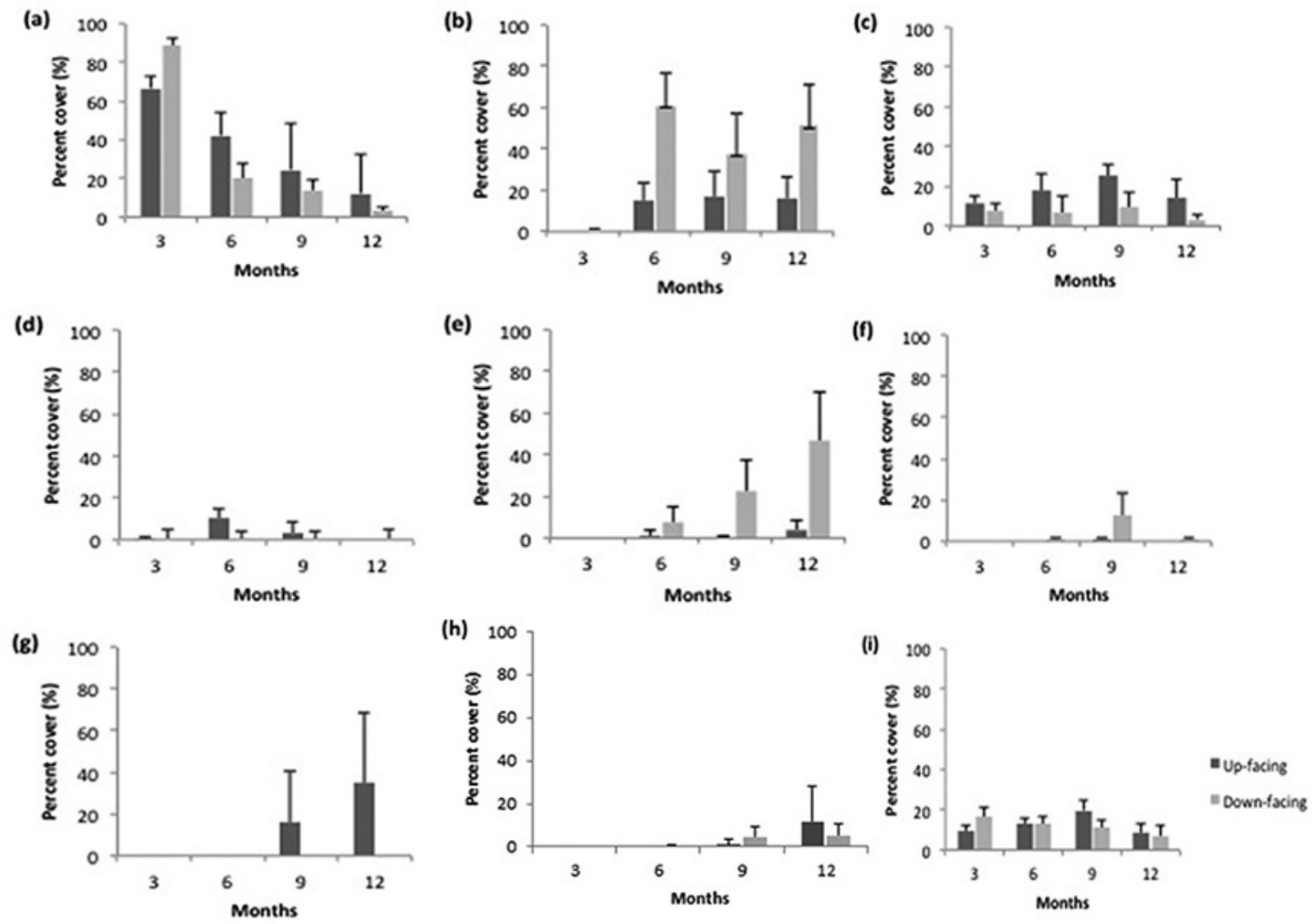

Figure 8. Mean values and standard deviations of the percent cover of the fouling organisms that contributed most to the dissimilarity between the up- and down-facing surfaces of the 3.5-m deep panels at 3, 6, 9, and 12 months (a. Filamentous algae, b. Hydrozoa, c. Cirripedia, d. Biofilm 2, e. Encrusting bryozoan, f. Crustose calcareous algae, g. Articulate calcareous algae, h. Sponge, i. Bare space).

MENGE (2000), oceanographic changes with ecologically significant consequences, such as variations in the supply of food, may occur in seasonal upwelling regimes.

Temperature is a key factor of biological patterns and processes that influence the vital biochemical and physiological rates, including the survival, growth and reproduction of organisms, and consequently determines "when" and "where" species can survive (DRINKWATER et al., 2010; KORDAS et al., 2011). The fouling community on Cabo Frio Island is composed of macroalgae and sessile filter feeders, whose internal temperatures vary considerably with fluctuations in the ambient temperature $\left(13.5\right.$ to $33{ }^{\circ} \mathrm{C}$ ) and are therefore strongly influenced by the physical characteristics of their local environment (COMA et al., 2000). SKINNER et al. (2007) have reported that, for a barnacle species Tetraclita stalactifera, higher temperatures may have a greater influence on growth than food availability in cold-water masses, such as the upwelling waters in the study area.

The supply of nutrients to plankton and benthic micro and macroalgae, and consequently filtering organisms, has a strong influence on bottom-up control of trophic systems (WIETERS et al., 2009) and therefore on the structure and dynamics of marine benthic communities (MENGE, 2000). In the region of Cabo Frio, GUIMARAENS et al. (2005) have suggested that the increased concentrations of nutrients during upwelling events can sustain greater algal biomass; this idea was confirmed by the predominance of filamentous algae at months 3,6 and 9 and articulated calcareous macroalgae at month 12 , mainly at $3.5 \mathrm{~m}$, up to threefold more upwelling events than at $1.5 \mathrm{~m}$.

The invertebrates recorded have dual life cycles involving a benthic adult stage and a planktonic larval stage. Successful colonisation, which is one of the successional stages, is dependent upon the availability of larvae. The expected pattern of larval transport during upwelling period is advection away from the coast, whilst during subsidence period the transport is directed towards the coast. The persistence of long periods of upwelling can lead to a loss of larvae that fail to return to attachment sites (reviewed by LÓPEZ; COUTINHO, 2008). Previous studies have demonstrated that the upwelling-subsidence 
(a)

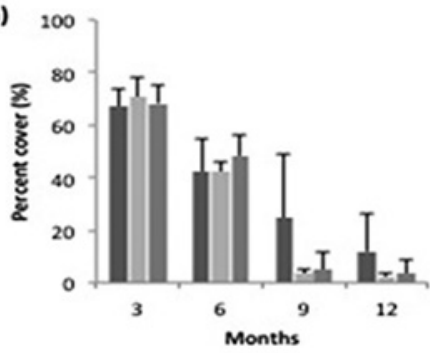

(b)

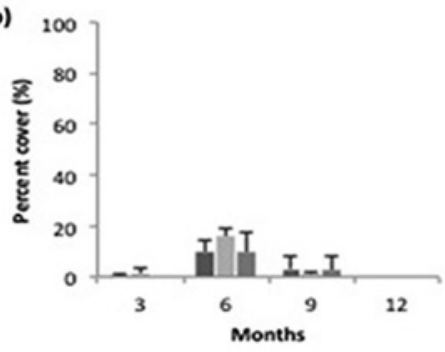

(c)

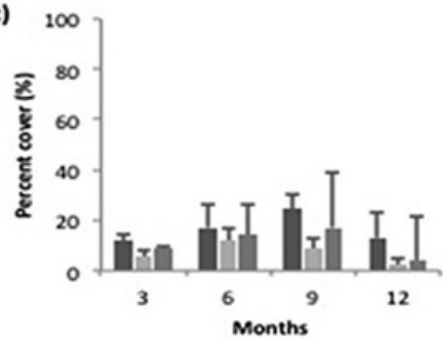

(d)

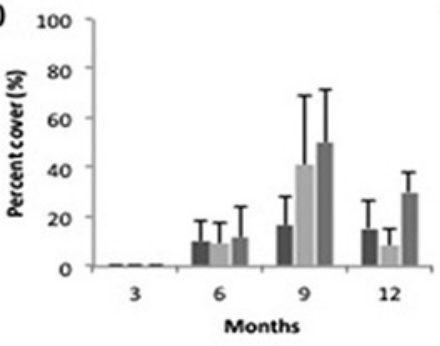

(e)

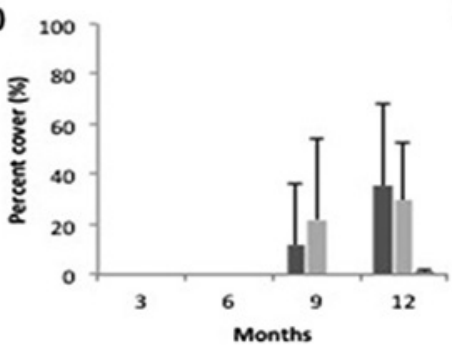

(f)

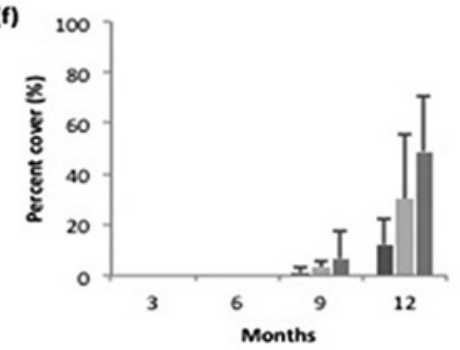

(8)

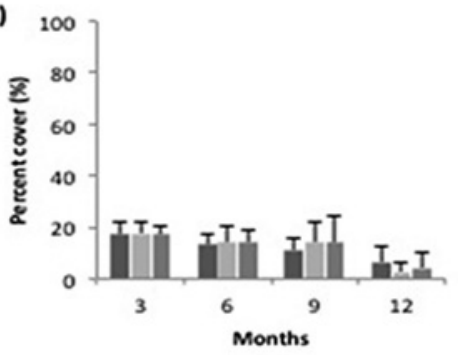

a Open panel

= full cage

n partial cage

Figure 9. Mean values and standard deviations of the percent cover of the fouling organisms that contributed most to the dissimilarities among the open, partially caged and fully caged panels at the 3.5-m depth before (month 3 and month 6) and after (month 9 and month 12) the introduction of sampling artefacts (a. Filamentous algae, b. Biofilm 2, c. cirripedia, d. Hydrozoa, e. Articulate calcareous algae, f. Sponge, g. Bare space).

Table 2. Fish present in the vicinity of the multi-experiment biofouling structure, including species, family, trophic group, and type of interaction.

\begin{tabular}{lccc}
\hline Species & Family & Trophic Group & Interaction \\
\hline Holocentrus adscensionis & Holocentridae & Carnivore $^{1}$ & Feeding \\
Pseudupeneus maculatus & Mullidae & Invertivore $^{1}$ & Feeding \\
Stephanolepis hispidus & Monacanthidae & Omnivore $^{1}$ & Feeding \\
Caranx sp. & Carangidae & Piscivore $^{2}$ & No interaction \\
Haemulon aurolineatum & Haemulidae & Invertivore $^{1}$ & Shelter \\
Halichoeres poeyi & Labridae & Invertivore $^{2}$ & No interaction \\
Diplectrum formosum & Serranidae & Carnivore $^{3}$ & No interaction \\
Kyphosus sectatrix & Kyphosidae & Herbivore $^{1}$ & No interaction \\
Abudefduf saxatilis & Pomacentridae & Omnivore $^{1}$ & Feeding \\
Diplodus argenteus & Sparidae & Omnivore $^{1}$ & Feeding \\
Acanthurus bahianus & Acanthuridae & Herbivore $^{1}$ & No interaction \\
Parablennius pilicornis & Blenniidae & Omnivore $^{3}$ & Shelter \\
Coryphopterus sp. & Gobiidae & Omnivore $^{1}$ & Shelter
\end{tabular}

Source: ${ }^{1}$ Ferreira et al. (2001), ${ }^{2}$ Ferreira et al. (2004), ${ }^{3}$ Gibran and Moura (2012). 
model can be applied to the Cabo Frio region, and this weather condition is important in determining the patterns of cirripedia larval supply and recruitment, reflected in both spatial and temporal variability (MAZZUCO et al., 2015).

The homogeneity of the water column during nonupwelling periods subjects the benthic assemblages at the two depths to similar environmental conditions, as reflected by the greater similarity between the communities at 9 and 12 months. The first hypothesis that the presence of the thermocline is influenced by seasonal upwelling events, and therefore, depth influences the successional trajectory of the fouling community was corroborated; the successional stages differed between 1.5 and $3.5 \mathrm{~m}$ during the austral spring-summer, when upwelling events are prevalent and cause stratification of the water column and the intrusion of cold, nutrient-rich waters. During the austral autumn-winter, there is a homogenisation of the water column, and the oceanographic conditions are more similar at both depths. In summary, the possibility of a convergence or divergence in the successional trajectory related to the seasonality of the local environmental conditions was observed in association with periods with or without upwelling.

The effect of light intensity (sevenfold greater on the up-facing side of the panels) on the successional trajectory of the fouling community was reflected in the dominance of sessile invertebrates in the more shaded environments at $3.5 \mathrm{~m}$ deep, with significant differences and increasing dissimilarity along the successional stages for both substrate orientations, with the dominance of photophyla species on the up-facing panels and scyaphyla ones on the down-facing panels. Two organisms played a key role in the observed pattern: articulated calcareous macroalgae (Jania sp.) were present only on the upfacing surface, whilst the fouling bryozoan Schizoporella errata occurred exclusively on the down-facing surface. Jania sp. requires light, which is more intense on the upfacing surface of the panel. The increasing coverage of the fouling bryozoan corroborates reports in the literature that Schizoporella adults strongly inhibit the recruitment and growth of other species at different periods in time (SUTHERLAND, 1978). The dominance of sessile invertebrates in the shaded areas is often explained by observations of larval behaviour in the laboratory, with many species, mainly bryozoans and ascidians, exhibiting photonegative behaviours at the end of their pelagic larval stage (reviewed by IRVING; CONNELL, 2002).
According to IRVING and CONNELL (2002), the abundance of sessile invertebrate on bottom-facing surfaces and the lower coverage of algae is a good indicator of low light intensity. However, this may not always be the main cause of such patterns; the build-up of sediments can be detrimental to the survival of various organisms, preventing or reducing larval settlement and favouring organisms that have already become established. The possible influence of sediment could be disregarded in our study, due to the relatively shallow depth, no continental influence on shallow waters that could alter this condition and active circulation, all of which acted to prevent the accumulation of sediment on the experimental panels.

The second hypothesis that a reduction in the intensity of natural light, related to the orientation of the substrate, influences the composition of the fouling community, and consequently the successional trajectory, was accepted. The down-facing panel surface experienced a significant reduction in light intensity, influencing the composition of the fouling community and its trajectory. According to PRACH and WALKER (2011) successional trajectories can be convergent, divergent, parallel, circular, or form complex networks of successional pathways. Comparing the up- and down-facing surfaces of the panels at Cabo Frio Island, the trajectories of the fouling community are classified as parallel because they differ from the beginning to the end of the panel immersion experiment.

Considering the effect of predation on the successional trajectory of the fouling community on Cabo Frio Island, the results suggest that the high predation intensity and their effects on the benthic composition are related to the predator trophic habit. Considering the trophic groups (omnivores, herbivores, invertivores and carnivores), fouling predation by fish was observed around the experimental structures. The species Stephanolepis hispidus, which is omnivorous and abundant at Cabo Frio Island (FERREIRA et al., 2004), was the most frequently species interacting directly with the experimental panels before the addition of cages. Bite marks were observed, indicating disturbance through predation of filamentous macroalgae at $3.5 \mathrm{~m}$. The typically tropical species Diplodus argenteus is common in Cabo Frio (FERREIRA et al., 2001) and was often recorded feeding on the panels. However, unlike $S$. hispidus, it was not possible to identify the prey of $D$. argenteus because this species displays a more erratic feeding behaviour. Their preys include algae, crustaceans, molluscs, and polychaetes (SAZIMA, 1986). Thus, predation played a fundamental role on the 
recolonization by filamentous algae, thus initiating a continuous successional process. Other papers regarding the effect of predator on fouling communities on Brazil include VIEIRA et al. (2016) and ORICCHIO et al. (2016).

Smallfish of the families Blenniidae and Gobiidae living in association with the substrate (GIBRAN; MOURA, 2012) were recorded inside the cages. The cages were designed to prevent access to fish, except small juveniles and Blenniidae and Gobiidae, which do not generally prey on sessile biota according to CONNELL (2001). The fouling assemblages in the open and partially caged panels differed significantly, indicating the potential influence of the sampling artefact on predation. One possible effect is shading, as the coverage of several species of algae is reduced under such conditions (GLASBY, 1999; IRVING; CONNELL, 2002). The lowest coverage of filamentous and articulated calcareous algae in the panels with partial cages compared to open panels corroborates the findings reported in the literature. The cage cleaning protocol was performed at an interval of 10 days, indicating the need for shorter intervals to minimise the influence of light.

Despite the influence of shading through the sampling artefact, a comparison of the fouling assemblages in the open and fully caged panels revealed significant differences at 9 and 12 months. The greater abundance of filamentous algae followed by barnacles on the open panels resulted from predation by Stephanolepis hispidus on the macroalgae, providing space for these opportunistic algae to recolonize and dominate, and consequently, the association remained on an early successional stage. Filamentous algal forms are more nutritious and digestible (FERREIRA et al., 1998). Recently, CECCARELLI et al. (2011) found that herbivorous fish (farmers) in the Great Barrier Reef in Australia had a drastic impact on succession, essentially precluding the development of the algal community, which was dominated by palatable filamentous algae.

Regarding the effect of predation, it is worth noting that up to the sixth month, before the inclusion of sampling artefacts, the panels did not differ significantly. After the installation of the full and partial cages, differences in the respective successional trajectories were observed. However, the detection of the artefact effect prevents us from accepting the alternative hypothesis that fish predation affects the fouling community.

It is possible to conclude that changes in hydrological characteristics associated with depth in a seasonal upwelling environment allowed for the formation of multiple stable states in the system (sensu SUTHERLAND, 1974; SUTHERLAND; KARLSON, 1977). In addition to the upwelling, which provided distinct water masses, light effect was a determining factor in the successional trajectory of the fouling community at a scale of 12 months.

The results of this study suggest that each physical factor can alter the trajectory of succession and, consequently, the composition of the community. The successional model acting on the fouling community will depend on the magnitude of the determinant factor (e.g. depth, light intensity), acting on the community at each stage. If the community tends to a particular successional trajectory, e.g. convergent, divergent, parallel or cyclic, it can change as the acting successional model varies over time. Therefore, the fate of a fouling community is not predetermined but is guided by intrinsic and extrinsic factors, which will act as determining factors of the changes in the successional model.

\section{ACKNOWLEDGEMENTS}

This work was funded by the Brazilian Agencies CNPq (Conselho Nacional de Desenvolvimento Científico e Tecnológico) and FAPERJ (Fundação de Amparo à Pesquisa do Estado do Rio de Janeiro FAPERJ/PRONEX Proc No E-26/111.438/2010). We are grateful to the Biofouling Laboratory (IEAPM) team for field assistance.

\section{REFERENCES}

BRAM, J. B.; PAGE, H. M.; DUGAN, J. E. Spatial and temporal variability in early successional patterns of an invertebrate assemblage at an offshore oil platform. J. Exp. Mar. Biol. Ecol., v. 317, p. 223-237, 2005.

BROTTO, D. S.; KROHLING, W.; ZALMON, I. R. Comparative evaluation of fish assemblages census on an artificial reef. Rev. Brasil. Zool., v. 24, n. 4, p. 1157-1162, 2007.

CECCARELLI, D. M.; JONES, G. P.; MCCOOK, L. J. Interactions between herbivorous fish guilds and their influence on algal succession on a coastal coral reef. J. Exp. Mar. Biol. Ecol., v. 399, n. 1, p. 60-67, 2011.

CLARKE, K. R.; WARWICK, R. M. Change in marine communities: an approach to statistical analysis and interpretation. 2nd ed. Plymouth: PRIMER-E, 2001. 172 p.

COMA, R.; RIBES, M.; GILI, J. M.; ZABALA, M. Seasonality in coastal benthic ecosystems. Trends Ecol. Evol., v. 15, n. 11, p. 448-453, 2000.

CONNELL, J. H.; SLATYER, R. O. Mechanisms of succession in natural communities and their role in community stability and organization. Am. Nat., v. 111, n. 982, p. 1119-1144, 1977. 
CONNELL, S. D. Predation fish do not always affect the early development of epibiotic assemblages. J. Exp. Mar. Biol. Ecol., v. 260 , n. 1, p. 1-12, 2001.

CONNELL, S. D.; ANDERSON, M. J. Predation by fish on assemblages of intertidal epibiota: effects of predator size and patch size. J. Exp. Mar. Biol. Ecol., v. 241, n. 1, p. 15-29, 1999.

DE MESSANO, L. V. R.; SATHLER, L.; REZNIK, L. Y.; COUTINHO, R. The effect of biofouling on localized corrosion of the stainless steels N08904 and UNS S32760. Int. Biodeter. Biodegr., v. 63, n. 5, p. 607-614, 2009

DRINKWATER, K. F.; BEAUGRAND, G.; KAERIYAMA, M.; KIM, S.; OTTERSEN, G.; PERRY, R. I.; PÖRTNER, H. O.; POLOVINA, J. J.; TAKASUKA, A. On the processes linking climate to ecosystem changes. J. Mar. Sys., v. 79, n. 3-4, p. 374-388, 2010.

FERREIRA, C. E. L.; GONÇALVES, J. E. A.; COUTINHO, R. Community structure of fishes and habitat complexity in a tropical rocky shore. Environ. Biol. Fishes, v. 61, n. 4, p. 353369, 2001.

FERREIRA, C. E. L.; FLOETER, S. R.; GASPARINI, J. L.; FERREIRA, B. P.; JOYEUX, J. C. Trophic structure patterns of Brazilian reef fishes: a latitudinal comparison. J. Biogeogr., v. 31, n. 7, p. 1093-1106, 2004.

FERREIRA, D. E. L.; PERET, A. C.; COUTINHO, R. Seasonal grazing rates and food processing by tropical fish. J. Fish Biol., v. 53, n. sA, p. 222-235, 1998.

GIBRAN, F. Z.; MOURA, R. L. The structure of rocky reef fish assemblages across a nearshore to coastal islands' gradient in Southeastern Brazil. Neotrop. Ichthyol., v. 10, n. 2, p. 369382, 2012.

GLASBY, T. M. Effects of shading on subtidal epibiotic assemblages. J. Exp. Mar. Biol. Ecol., v. 234, n. 2, p. 275-290, 1999.

GUIMARAENS, M. A.; PAIVA, A. M.; COUTINHO, R. Modeling Ulva spp. dynamics in a tropical upwelling region. Ecol. Modell., v. 188, n. 2-4, p. 448-460, 2005.

HACKRADT, C. W.; FÉLIX-HACKRADT, F. C.; GARCÍA-CHARTON, J. A. Influence of habitat structure on fish assemblage of an artificial reef in southern Brazil. Mar. Environ. Res., v. 72, n. 5, p. 235-247, 2011.

HINRICHSEN, H. H. Biological processes and links to the physics. Deep Sea Res. Part II Top. Stud. Oceanogr., v. 56, n. 21-22, p. 1968-1983, 2009.

HUSTON, M. A. \& SMITH, T. M. 1987:Plant succession: life history and competition. Am. Nat. 130: 168-198.

IRVING, A. D.; CONNELL, S. D. Sedimentation and light penetration interact to maintain heterogeneity of subtidal habitats: algal versus invertebrate dominated assemblages. Mar. Ecol. Progr. Ser., v. 245, p. 83-91, 2002

ITIS - Integrated Taxonomic Information System. 2009. Available at: < http://www.itis.gov>. Accessed: 1 Sep. 2016.

KOHLER, K. E.; GILL, S. M. Coral Point Count with Excel extensions (CPCe): A Visual Basic program for the determination of coral and substrate coverage using random point count methodology. Comput. Geosci., v. 32, n. 9, p. 1259-1269, 2006.

KORDAS, R. L.; HARLEY, C. D. G.; O'CONNOR, M. I. Community ecology in a warming world: The influence of temperature on interspecific interactions in marine systems. J. Exp. Mar. Biol. Ecol., v. 400, n. 1-2, p. 218-226, 2011.
LAWTON, J. H. Are there assembly rules for successional communities? In: GRAY, A. J.; CRAWLEY, M. J.; EDWARDS, P. J. (Eds.). Colonization, succession and stability. Oxford: Blackwell Scientific Publications, 1987. p. 225-244.

LÓPEZ, M. S.; COUTINHO, R. Acoplamento Plâncton-Bentos: o papel do suprimento larval na estrutura das comunidades bentônicas de costões rochosos. Oecol. Brasili., v. 12, n. 4, p. 575-601, 2008.

MAHIQUES, M. M.; BICEGO, M. C.; SILVEIRA, I. C. A.; SOUSA, S. H. M.; LOURENÇO, R. A.; FUKUMOTO, M. M. Modern sedimentation in the Cabo Frio upwelling system, Southeastern Brazilian shelf. An. Acad. Brasil. Ciênc., v. 77, n. 3, p. 535-548, 2005.

MASI, B. P.; COUTINHO, R.; ZALMON, I. Successional trajectory of the fouling community on a tropical upwelling ecosystem in southeast Rio de Janeiro, Brazil. Braz. J. Oceanogr., v. 63, n. 2, p. 161-168, 2015.

MAZZUCO, A. C. A.; CHRISTOFOLETTI, R. A.; PINEDA J.; STARCZAK, V. R.; CIOTTI, A. M. Temporal variation in intertidal community recruitment and its relationships to physical forcings, chlorophylla concentration and sea surface temperature. Mar. Biol., v. 162, n. 9, p. 1705-1725, 2015.

MENGE, B. A. Top-down and bottom-up community regulation in marine rocky intertidal habitats. J. Exp. Mar. Biol. Ecol., v. 250, n. 1-2, p. 257-289, 2000.

MENGE, B. A.; ALLISON, G. W.; BLANCHETTE, C. A.; FARRELL, T. M.; OLSON, A. M.; TURNER, T. A.; VAN TAMELEN, P. Stasis or kinesis? Hidden dynamics of a rocky intertidal macrophyte mosaic revealed by a spatially explicit approach. J. Exp. Mar. Biol. Ecol., v. 314, n. 1, p. 3-39, 2005.

ORICCHIO, F. T.; FLORES, A. A. V.; DIAS, G. M. The importance of predation and predator size on the development and structure of a subtropical fouling community. Hydrobiologia, v. 776, n. 1, p. 209-219, 2016.

PAWLIK, J. Induction of marine invertebrate larval settlement: evidence for chemical cues. In: PAUL, V. J. (Ed.). Ecological roles of Marine Natural Products. New York: Cornell University Press, 1992. p. 189-236.

PRACH, K.; WALKER, L. R. Four opportunities for studies of ecological succession. Trends Ecol. Evol., v. 26, n. 3, p. 119123, 2011.

QVARFORDT, S.; KAUTSKY, H.; MALM, T. Development of fouling communities on vertical structures in the Baltic Sea. Estuar. Coast. Shelf Sci., v. 67, n. 4, p. 618-628, 2006.

RIER, S. T.; STEVENSON, R. J.; LALIBERTE, G. D. Photo-acclimation response of benthic stream algae across experimentally manipulated light gradients: a comparison of growth rates and net primary productivity. J. Phycol., v. 42, n. 3, p. 560-567, 2006.

ROBERTS, L. W.; BUTCHER, P. A.; BROADHURST, M. K.; CULLIS, B. R. Using a multi-experimental approach to assess the fate of angled-and-released yellowtail kingfish ( $\mathrm{Se}$ riola lalandi). ICES J. Mar. Sci., v. 68, n. 1, p. 67-75, 2011.

SAZIMA, I. Similarities in feeding behaviour between some marine and freshwater fishes in two tropical communities. J. Fish Biol., v. 29, n. 1, p. 53-65, 1986.

SKINNER, L. F.; SIVIERO, F. N.; COUTINHO, R. Comparative growth of the intertidal barnacle Tetraclita stalactifera (Thoracica: Tetraclitidae) in sites influenced by upwelling and tropical conditions at the Cabo Frio region, Brazil. Rev. Biol. Trop., v. 55, Suppl. 1, p. 71-78, 2007. 
SOUSA, W. P. Natural disturbance and the dynamics of marine benthic communities. In: BERTNESS, M. D.; GAINES, S. D.; HAY, M. E. (Eds.). Marine Community Ecology. Sunderland: Sinauer Associates, 2001. p. 85-130.

STARK, J. S. Patterns of higher taxon colonisation and development in sessile marine benthic assemblages at Casey Station, Antarctica, and their use in environmental monitoring. Mar. Ecol. Progr. Ser., v. 365, p. 77-89, 2008.

SUTHERLAND, J. P. Multiple stable points in natural communities. Am. Nat., v. 108, p. 859-873, 1974.

SUTHERLAND, J. P. Functional roles of Schizoporella and Styela in the fouling community at Beaufort, North Carolina. Ecology, v. 59, n. 2, p. 257-264, 1978.

SUTHERLAND, J. P. The structure and stability of marine macrofouling communities. In: COSTLOW, J. D.; TIPPER, R. C. (Eds.). Marine biodeterioration: an interdisciplinary study. Annapolis: United States Naval Institute, 1984. p. 202-206.

SUTHERLAND, J. P.; KARLSON, R. H. Development and stability of the fouling community at Beaufort, North Carolina. Ecol. Monogr., v. 47, n. 4, p. 425-446, 1977.
TILMAN, D. Constraints and tradeoffs: toward a predictive theory of competition and succession. Oikos, v. 58, n. 1, p. 3-15, 1990.

VALENTIN, J. L.; ANDRE, D. L.; JACOB, S. A. Hydrobiology in the Cabo Frio (Brazil) upwelling: two-dimensional structure and variability during a wind cycle. Cont. Shelf Res., v. 7, p. 77-88, 1987.

VIEIRA, E. A.; DUARTE, L. F. L.; DIAS, G. M. How the timing of predation affects composition and diversity of species in a marine sessile community? J. Exp. Mar. Biol. Ecol., v. 412, p. 126-133, 2012.

VIEIRA, E. A.; DIAS, G. M.; FLORES, A. A. V. Effects of predation depend on successional stage and recruitment rate in shallow benthic assemblages of the Southwestern Atlantic. Mar. Biol., v. 163, p. 87, 2016.

WIETERS, E. A.; BROITMAN, B. R.; BRANCH, G. M. Benthic community structure and spatiotemporal thermal regimes in two upwelling ecosystems: comparisons between South Africa and Chile. Limnol. Oceanogr., v. 54, n. 4, p. 1060-1072, 2009. 